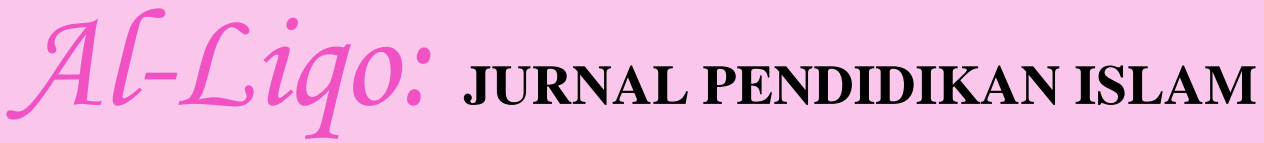 \\ P-ISSN: 2461-033X | E-ISSN: 2715-4556
}

\section{Pendidikan Anak Perspektif Psikologi}

\author{
Nurliana Nurliana ${ }^{1)}$, Miftah Ulya ${ }^{2)}$ \\ Email: nurliana@diniyah.ac.id ${ }^{1}$, miftah@diniyah.ac.id $^{2}$ \\ ${ }^{1,2)}$ STAI Diniyah Pekanbaru, Riau, Indonesia
}

\begin{abstract}
The success of children's education is the success of a nation. Teachers must understand the psychology of learning so that education can play a role and influence children. This research was descriptive in the form of library research which was formulated through deductive analysis. Research on children's education with a psychological perspective needs to be carried out to determine the acceptance of children to the environment (family, school, and surroundings) in providing valuable education for children in line with their psychological development, and they can undergo the learning process through a conducive environment.
\end{abstract}

Keywords: Psychology, Children, Education

\begin{abstract}
Abstrak
Keberhasilan pendidikan anak dipandang sebagai keberhasilan suatu bangsa, sehingga proses pendidikan harus memiliki orientasi terhadap masyarakat dan sistem sosial. Guru harus memahami psikologi belajar agar pendidikan bisa berperan dan berpengaruh terhadap anak. Penelitian ini merupakan penelitian deskriptif dalam bentuk library reseach yang diformulasikan melalui metode pemikiran deduktif. Penelitian pendidikan anak perspektif psikologi perlu untuk dilakukan untuk mengetahui penerimaan anak terhadap lingkungan keluarga, lingkungan sekolah dan lingkungan sekitarnya sehingga memberi nilai pendidikan yang berharga bagi anak seiring perkembangan psikologis anak, dan anak bisa menjalani proses belajar melalui lingkungan yang kondusif.
\end{abstract}

Kata Kunci: Psikologi, Anak, Pendidikan

Cara Mensitasi Artikel:

Nurliana, N., \& Ulya, M. (2021). Pendidikan anak perspektif psikologi. Al-Liqo: Jurnal Pendidikan Islam, 6(1), 56-67. https://doi.org/10.46963/alliqo.v6i1.313.

*Corresponding Author:

nurliana@diniyah.ac.id

Editorial Address: Kampus Parit Enam, STAI Auliaurrasyidin Tembilahan. Jl. Gerilya No. 12 Tembilahan Barat, Riau Indonesia 29213.

\begin{tabular}{|c|c|}
\hline \multicolumn{2}{|c|}{ Histori Artikel: } \\
\hline Diterima & : 23/02/2021 \\
\hline Direvisi & : 30/06/2021 \\
\hline Diterbitkan & : 30/06/2021 \\
\hline
\end{tabular}

DOI: https://doi.org/10.46963/alliqo.v6i1.313

\section{PENDAHULUAN}

Aktivitas dunia pendidikan di era digitalisasi semakin mendapat tantangan bahkan juga menjadi peluang, seiring perkembangan sistem sosial yang berkembang di masyarakat. Persoalan pendidikan harus mendapat tempat dan raung serta solusi terbaik di masyarakat. Sistem pendidikan memiliki peran yang kuat dalam mentransformasikan nilai-nilai pendidikan dalam kehidupan. Peningkatan sistem pendidikan di suatu negara ditandai adanya kemajuan ilmu pengetahuan dan 
teknologi dan terpeliharanya sistem nilai moral yang berlaku di dalam masyarakat. Perkembangan pendidikan kontemporer terlihat sebagai distorsi pendidikan yang penuh tantangan. Kehadiran suatu kurikulum yang mengintegrasikan sistem nilai ilmu pengetahuan dan sistem sosial yang berkembang di masyarakat dianggap suatu kurikulum yang mampu mengendalikan gejolak sosial yang terjadi di masyarakat sekaligus solusi mengikuti perkembangan ilmu pengetahuan dan teknologi. Tenaga pendidik khususnya guru hendaknya membutuhkan ragam pengetahuan terutama psikologi yang memadai sesuai tuntutan zaman dan kemajuan sains dan teknologi untuk mengentaskan persoalan pada dunia pendidikan, Muhibin Syah (2015: 1).

Dalam ilmu psikologi, pembentukan moral pada diri seseorang terjadi pada masa usia dini rentang 0-8 tahun. Usia ini merupakan awal pertumbuhan dan perkembangan, pendidikan yang diberikan pada usia ini merupakan masa emas yang begitu berpengaruh terhadap perkembangan di masa mendatang. Pendidikan di masa usia dini merupakan fondasi awal pembentukan kepribadian seorang anak. Namun karena manusia dalam hidupnya selalu mengalami suatu perubahan dan membutuhkan penentuan sikap dalam setiap fenomena yang terjadi sehingga dikatakanlah pendidikan seumur hidup (long life education). Kita dituntut belajardan belajar lagi, Rohmalina Wahab (2015: 2).

Anak yang mendapatkan pembinaan sejak dini akan dapat meningkatkan kesehatan dan kesejahteraan fisik dan mental, yang itu akan berdampak pada peningkatan prestasi belajar, etos kerja, dan produktivitas. Dengan bekal ini anak akan lebih mampu untuk mandiri dan mengoptimalkan potensi yang telah dianugerahkan Tuhan kepadanya. Di awal tahun, anak belajar di sekolah masa inilah yang penting untuk memberikan dasar, kepada anak-anak bagaimana mereka sebaiknya belajar dan berusaha untuk mencapai keberhasilannya dikemudian hari. Berbagai ilmu mendasar dipelajari di awal-awal tahun sekolah dasar, mulai bagaimana caranya membaca, menulis, dan berhitung, bahkan bagaimana pula caranya berbicara dalam sebuah diskusi dalam kelasnya, Chairinniza Graha (2007: 3).

Pendidikan anak perspektif psikologi untuk memahami dan menghadirkan suasana yang menyenangkan bagi anak didik, dalam suasana ini anak bisa 
mendapatkan nilai-nilai pendidikan dari apa yang ia lewati, dan menjadikan belajar cukup menyenangkan. Pertama kali anak-anak mendapat pengalaman bagaimana ia mendapatkan pekerjaan rumah yang harus dikerjakan, kemudian dibawa kembali ke sekolah untuk diperiksa gurunya untuk mendapatkan nilai. Dengan tugas yang diterima dan dikerjakan anak, mereka mendapatkan kesempatan bagaimana bekerja dan berusaha dengan baik dalam menyelesaikan tugasnya agar mendapat nilai yang baik pula. Menurut para ahli mengajar anak di saat masih baru mengenal sesuatu lebih mudah dan lebih besar kemungkinan untuk berhasil. Hal ini disebabkan anak masih baru mengenal hal baru dalam pengalaman hidupnya, rasa ingin tahu seorang anak begitu tinggi dan antusias.

Penelitian ini bagian dari sesuatu yang urgen untuk dilakukan untuk memahami situasi yang mempengaruhi pendidikan anak perspektif psikologi, sembari mengetahui bagaimana penerimaan anak terhadap lingkungan keluarga, lingkungan sekolah dan lingkungan sekitarnya sehingga memberi nilai pendidikan yang berharga bagi anak seiring mempengaruhi perkembangan psikologis anak.

\section{METODE}

Penelitian ini merupakan penelitian deskriptif kualitatif dalam bentuk library reseach. Penulis memformulasikan penulisan ini melalui metode pemikiran deduktif, dengan memaparkan pembahasan secara global kemudian memfokus pada kajian yang dimaksud untuk memperoleh gambaran hasil penelitian sebagai kesimpulan. Library research yaitu mengumpulkan buku-buku yang berkaitan dengan objek penelitian atau penelitian yang bersifat kepustakaan. Kajian yang penulis gunakan adalah penelitian perpustakaan murni, penulis akan menggunakan Sumber Primer yaitu buku rujukan awal dan utama dalam penelitian, sumber primer yang penulis gunakan adalah:

Akmal Hawi, Seluk Beluk Ilmu Jiwa Agama, (Jakarta: Raja Grafindo Persada, 2014), Bimo Walgito, Pengantar Psikologi Umum, (Yogyakarta: ANDI, 2010). Muhibin Syah, Psikologi Belajar, (Jakarta: raja Grafindo Persada, 2015), Rohmalina Wahab, Psikologi Belajar, (Jakarta: Raja Grafindo Persada, 2015). Rosleni, Asiyah, Psikologi Islam, (Bandung: Pustaka setia, 2015), Sarlito W 
Pendidikan Anak Perspektif Psikologi

Sarwono, Psikologi Remaja, (Jakarta: Raja Grafindo Persada, 2010). Sri Rumini, Siti Sundari, Perkembangan Anak dan Remaja, (Jakarta: Rineka Cipta, 2004). Syamsu Yusuf, Psikologi Perkembangan Anak dan Remaja, (Bandung: Rosda Karya, 2008). Zakiah Darajat, Ilmu Jiwa Agama, (Jakarta: Bulan Bintang, 2010).

\section{HASIL DAN PEMBAHASAN}

Pendidikan merupakan aset yang berharga untuk kemajuan suatu bangsa, oleh karenanya setiap warga Negara harus dan wajib mengikuti jenjang pendidikan, baik jenjang pendidikan anak usia dini, pendidikan dasar, pendidikan menengah maupun tinggi. Pemahaman mengenai karakteristik anak sesuai pertumbuhan dan perkembangannya. Jika perkembangan anak selama mengecam pendidikan berjalan dengan baik maka dengan sendirinya akan berpengaruh baik kepada anak dalam menentukan sikap dan dalam sekaligus juga pembentukan kepribadian. Proses belajar perlu menyesuaikan dengan usia perkembangan anak dari segi intelektual, sosial dan emosional.

Pendidikan merupakan suatu proses kehidupan manusia dengan tujuan mengimplementasikan nilai-nilai religius, nilai sosial kemasyarakatan dalam kehidupan seiring mengikuti perkembangan ilmu pengetahuan dan teknologi. Pendidikan pada hakikatnya adalah "process leading to the enlightement of mankind". Sebagai upaya mengaktualisasikan potensi yang dimiliki untuk peningkatan ke tahap yang lebih baik, Akmal Hawi, 2014: 13).

Orang bijak berujar, you are actuality bigger, higher, and greater than what you think, "Anda sebenarnya lebih besar, lebih hebat, lebih luar biasa dari apa yang Anda pikirkan. Manusia merupakan makhluk ciptaan Allah yang sempurna, dikaruniai banyak potensi, keunggulan serta kelebihan yang diberikan Allah. Diantaranya potensi akal, potensi hati, potensi roh, potensi fisik, Iirfan el-Qudsy (2010: 25). Irfan el-Qudsy, Keajaiban Berfikir Positif, (yogyakarta: Media Baca, 2010)

Dengan motivasi yang diberikan orang tua, anak-anak akan selalu bersemangat untuk maju dan belajar dengan baik. Dasar-dasar yang diberikan dengan baik dapat dijalani oleh anak -anak dengan baik pula menjadikan fondasi 
yang kokoh dalam diri anak. Dengan fondasi yang baik dan kokoh dapat memberikan perawatan yang baik maka anak akan menuju keberhasilan. Pendidikan tidak semuanya dari sekolah tetapi dibutuhkan kerja sama yang baik antara guru dan orang tua, keterpaduan keduanya akan membentuk fondasi sebagai dasar pendidikan anak, dan awal yang baik bagi anak.

Dalam pendidikan harus ditanamkan pada pikiran seseorang untuk keberhasilan suatu pendidikan yang dilewati, psikologi anak tergantung pada pikiran orang tua, orang tua harus memiliki visi, misi dan tujuan dalam hidup. Kita harus mempunyai impian yang besar dan keinginan untuk terus berkembang menjadi lebih baik. Visi, misi dan impian merupakan sumber datangnya motivasi dalam diri seseorang. Semakin besar visi, misi dan impian yang dimiliki seseorang maka semakin besar pula motivasi dalam diri tersebut. Karena motivasi sangat berpengaruh memberikan energi dalam tubuh, sehingga tidak mengherankan bila dirinya senantiasa termotivasi, energi yang lebih besar dari pada orang yang tidak memiliki motivasi.

Belajar memainkan peran penting dalam mempertahankan kehidupan manusia di tengah persaingan yang semakin ketat. Akibat persaingan kenyataan tragis bisa terjadi. "tidak sedikit orang pintar menggunakan kepintarannya untuk membuat orang lain terpuruk bahkan menghancurkan kehidupannya".

Konsep dasar belajar dalam Islam "Carilah Ilmu mulai dari ayunan hingga ke liang Lahat" atau Long Life Education. Belajar sepanjang hayat adalah suatu kosep, suatu ide, gagasan pokok Islam, belajar tidak hanya di lembaga pendidikan formal tetapi juga pada lembaga pendidikan nonformal. Pada taraf perkembangan selanjutnya belajar sepanjang hayat mulai mengembangkan tujuan-tujuan yang bersifat sosial. Disadari proses belajar mengajar bermanfaat bagi masyarakat secara keseluruhan, maka masyarakat menjadi dinamis lebih mudah menerima gagasan pembaharuan, lebih mudah berinteraksi di masyarakat, Rohmalina Wahab (2015: $61)$.

Dasar pendidikan merupakan fakta dan prinsip yang melandasi kebijakan dan praktik pendidikan yang berharga. Prinsip-prinsip ini adalah dasar dibangunnya rumah pendidikan. Jika dasar itu adalah substansial, sandaran dari struktur 
Pendidikan Anak Perspektif Psikologi

kemungkinan akan kuat, dan sebaliknya. Pendidikan anak perspektif psikologi yang dimaksud yaitu

\section{Orang Tua sebagai partner Anak}

Anak-anak membutuhkan seseorang yang bisa menjadi tempat mencurahkan perasaan mereka dalam menjalani petualangan baru disekolah. Orang tua sebagai orang yang sangat dekat dengan anak selayaknya menjadi tempat bagi anak-anak untuk mencurahkan perasaannya, Chairinniza Graha (2007: 5).

Membiasakan menjalin komunikasi yang akrab antara anak dan orang tua dengan demikian akan membantu sebuah kepercayaan pada diri anak, mereka mau membicarakan permasalahan dan kesulitan yang dihadapinya dengan terbuka. Dengan terjalinya komunikasi antara orang tua dan anak maka orang tua sangat membantu dalam menyelesaikan permasalahan anak.

1. Konsisten dalam mendidik anak

Banyak kalangan orang-tua mengasosiasikan pendidikan itu sebagai tugasnya sekolah. Sehingga dalam mindset nya, pendidikan hanya didapat di lingkungan sekolah. Ayah dan ibu harus memiliki sikap dan perlakuan yang sama dalam melarang dan membolehkan tingkah laku tertentu pada anak. Suatu tingkah laku anak yang dilarang orang tua pada suatu waktu harus juga dilarang apabila dilakukan kembali pada waktu yang lain, Syamsu Yusuf (2008: 131).

Berdasarkan hasil penelitian sekitar 50\% kapabilitas kecerdasan orang dewasa telah terjadi ketika berumur 4 tahun,8 $0 \%$ telah terjadi perkembangan yang pesat tentang jaringan otak ketika anak berumur 8 tahun dan mencapai puncaknya ketika anak berumur 18 tahun, dan setelah itu walaupun tidak lagi terjadi perkembangan kognitif walaupun melalui perbaikan nutrisi. Perkembangan yang terjadi pada 4 tahun pertama sama besar pengaruhnya pada perkembangan 14 tahun berikutnya. Maka periode perkembangan anak pada masa ini merupakan perkembangan yang signifikan dan besar pengaruhnya terhadap personal seseorang. Masa emas ini merupakan masa emas pertumbuhan seorang anak. Hendaknya orang tua dan guru berperan penting pada masa ini perkembangan ini pada anak sehingga menjadi generasi harapan orang tua, bangsa dan negara yang siap mewujudkan peluang dan bisa 
mengatasi tantangan. Dengan konsisten memberikan bimbingan dan contoh yang baik maka sifat dan kebiasaan yang baik juga menjadi contoh bagi anak dalam bersikap.

2. Keteladanan orang tua

Keteladanan orang tua memiliki peran penting dalam perkembangan fisik dan psikologis anak terutama masa pertumbuhan sekaligus juga penentu moral pendidikan anak. Kebiasaan sikap otoriter yang dimiliki orang tua akan menjadikan anak bersikap egois dan otoriter juga. Sikap lemah lembut dan santun yang diperankan orang tua baik dalam keluarga ataupun pada orang lain juga mencerminkan pada anak bagaimana menjalin kasih sayang dan silaturahmi serta tata krama yang baik pada orang lain. Orang tua merupakan cermin bagi anak dalam bersikap dan bertingkah laku. Panutan pertama yang berperan terhadap seorang anak ialah orang tua. Jika orang tua tidak berpengaruh terhadap anaknya, maka anak akan mencari orang lain yang dianggap berperan terhadap dirinya bahkan anak akan mengidolakan orang lain, apakah selebriti, intelektual, ataupun musisi. Maka peran orang tua begitu diharapkan pada masa perkembangan dan pertumbuhan anak.

Orang tua yang tidak menghendaki anaknya berbohong, atau berlaku tidak jujur, maka orang tua harus menjauhkan dirinya dari perilaku berbohong atau tidak jujur. Apabila orang tua mengajarkan pada anak, agar berperilaku jujur, bertutur kata yang sopan, bertanggung jawab dan taat pada agama, tetapi orang tua menampilkan perilaku sebaliknya, maka anak akan mengalami konflik pada dirinya dan akan menggunakan ke tidak konsistenan orang tua sebagai alasan untuk tidak melakukan apa yang diinginkan oleh orang tuanya, bahkan mungkin akan berperilaku seperti orang tuanya.

3. Penghayatan dan pengamalan agama

Orang tua merupakan teladan yang baik terhadap anak-anaknya termasuk dalam pengamalan nilai agama begitu menentukan Nilai-nilai keislaman menjadi standar dalam penilaian perkembangan pendidikan anak dalam bersosial, dalam pengamalan agama anak lebih mencontoh orang tua dari segi berperilaku dalam ibadah dan lainnya, jika hanya ucapan saja maka hal 
Pendidikan Anak Perspektif Psikologi

demikian tidaklah berpengaruh kepada anak tanpa keteladanan beragama yang juga diperankan oleh orang tua, Rosleni, Asiyah (2015: 5).

\section{Guru Yang Kreatif}

Pendidikan tidak hanya berbicara sekolah. Pendidikan sejatinya adalah usaha bersama dalam mengajarkan suatu hal baik agar seseorang tahu, mengerti, dan mau menerapkan nilai-nilai yang dipelajarinya dalam kehidupan sehari-hari. Setelah lingkungan keluarga, maka lingkungan sekolah menjadi tempat di mana seharusnya pendidikan karakter ditegakkan dengan baik. Pemerintah lewat kementerian yang membidangi pendidikan telah berupaya agar pendidikan karakter menjadi Basic dari setiap ilmu pengetahuan. Sehingga nilai-nilai karakter tidak boleh luput dari setiap pembelajaran.

Nilai karakter merupakan penjelmaan dari nilai sosial yang berkembang di masyarakat, melalui pendidikan nilai karakter bagian dari tujuan pendidikan nasional dalam menyikapi fenomena kehidupan. Sehingga guru yang mengajar hendaklah menjadi panutan di masyarakat dengan nilai karakter kepribadiannya sekaligus menjadi contoh bagi anak-anak didik dan masyarakat. Apabila guru yang mengajar sudah balance antara aktivitas di sekolah dan di masyarakat maka akan mudah baginya untuk mentransfer ilmu pengetahuan dan nilai-nilai norma yang berkembang di masyarakat. Maka tujuan dari pembelajaran akan tercapai untuk skala nasional sembari mengikuti perkembangan ilmu pengetahuan dan teknologi. Anak didik pun akan mudah membentuk karakter yang dinginkan dari tujuan pembelajaran tentu saja melalui metode pembelajaran yang bervariasi yang digunakan oleh para guru dalam menghadapi dan melakukan tindakan sesuai perkembangan psikologis anak dan perkembangan kemampuan intelektualnya. Secara umum pendidikan bertujuan untuk menumbuh kembangkan potensi anak yang dibingkai dengan ilmu pengetahuan dan teknologi dengan dasar nilai moral dan etika.

Pendidikan dan pengajaran berbeda dalam tujuan, tujuan pendidikan ialah untuk membuat seseorang menjadi dewasa, tujuan pengajaran yang terbatas untuk membantu seseorang untuk menguasai subjek atau keterampilan pendidikan yang 
lebih umum dari mengajar, Rohmalina Wahab (2005: 80). Dalam hal ini dibutuhkan guru yang kreatif, dengan melakukan beberapa hal:

1. Menggairahkan anak didik.

Dalam proses pembelajaran guru harus berusaha menghindari hal-hal yang monoton dan membosankan. Guru harus memelihara minat anak didik dalam belajar dengan memberikan kebiasaan tertentu untuk meningkatkan kegairahan anak didik, guru harus mempunyai pengetahuan yang cukup mengenai kepribadian peserta didik. Sejak bayi manusia dapat berpikir dengan cara-cara tertentu, makin bertambah usia cara berpikir mengalami perubahan, Sri Rumini, Siti Sundari (2004: 69).

2. Memberikan harapan realistis

Guru harus memberikan harapan dan memodifikasi harapan agar realistis mengenai keberhasilan masa depan, dengan begitu mengarahkan berpikir optimis. Untuk mencapai kebahagiaan ada faktor yang dapat mempengaruhi seperti kekayaan, kesehatan yang baik dan persahabatan dengan orang lain, namun penentu kebahagiaan adalah pikiran kita, apabila kita memiliki pikiran yang tenang dan damai faktor kebahagiaan tersebut bisa berpengaruh, Arvan Pradiansyah (2010: 43).

3. Memberikan reward

Bila peserta didik mengalami keberhasilan guru hendaknya memberikah hadiah atau reward serta pujian atas keberhasilannya, sehingga peserta didik termotivasi untuk berbuat lebih baik lagi. Motivasi pujian lebih baik dari pada memberikan motivasi hukuman, Rohmalina Wahab (2005: 131).

4. Mengarahkan perilaku anak didik

Pendidikan tidak hanya dipandang kegiatan investasi untuk masa depan, namun harus berbicara sampai sejauh mana mampu memberikan kontribusi positif bagi penyelesaian permasalahan kekinian. Masa lampau menjadi fondasi dasar untuk pijakan bagi pengembangan selanjutnya. Guru harus berlapang dada dan berusaha memahami latar belakang sikap anak, membimbingnya ke arah yang menumbuhkan sikap yang positif terhadap sekolah, orang tua dan lingkungannya. 
Pendidikan Anak Perspektif Psikologi

Hubungan murid dan guru hendaknya berdasarkan saling pengertian, kasih sayang, sehingga murid itu terhormat dan sayang kepada gurunya. Hubungan yang baik itu akan membantu kecintaan anak terhadap pelajaran yang diberikan, Zakiah Darajat (2010: 79).

\section{Lingkungan Yang Baik}

Kondisi lingkungan masyarakat akan mempengaruhi belajar, dan kepribadian anak didik, seperti lingkungan yang kumuh, adanya pengangguran, anak terlantar, dan lingkungan kriminal lainnya. Lingkungan alamiah merupakan faktor-faktor yang dapat mempengaruhi aktivitas belajar anak didik, bila kondisi lingkungan alam tidak mendukung, proses belajar akan terhambat, Rohmalina Wahab (2015 :31).

Dalam upaya membangun pendidikan yang baik kepada anak dalam upaya mendidik dan membimbing, agar mereka dapat mengembangkan potensi dirinya secara optimal, maka bagi para pendidik, orang tua, atau siapa saja yang berkepentingan dalam pendidikan anak, perlu memahami perkembangan anak agar mampu mempengaruhi perkembangan anak. Berbagai upaya untuk memfasilitasi perkembangan anak, mencegah berbagai kendala atau faktor yang mungkin akan mengontaminasi perkembangan anak.

Peran pendidikan dipahami bukan saja dalam konteks mikro (kepentingan anak didik melalui proses interaksi pendidikan) melainkan juga dalam konteks makro, yaitu kepentingan masyarakat bangsa, negara dan kemanusiaan. Hubungan antara pendidikan dan masyarakat berarti mencakup hubungan pendidikan dengan perubahan sosial, tatanan ekonomi, politik dan negara.

Peserta didik dipandang sebagai orang yang merupakan bagian dari masyarakat, sehingga proses pendidikan harus memiliki orientasi terhadap masyarakat. Pendidikan adalah sebuah proses sosial bagi orang yang belum maupun sudah dewasa untuk menjadi bagian aktif dan partisipatif dalam masyarakat. Pengaruh pendidikan dan pengaruh lingkungan sebenarnya terdapat perbedaan. Pada umumnya pengaruh lingkungan bersifat pasif dan lingkungan tidak memberikan suatu paksaan kepada individu. Lingkungan memberikan kemungkinan-kemungkinan dan kesempatan pada individu. Sementara pendidikan 
bersifat aktif penuh tanggung jawab dan ingin mengarahkan perkembangan individu ke suatu tujuan tertentu, Bimo Walgito (2010: 54).

Kemerdekaan terdiri dari mandiri, berdiri sendiri, tidak tergantung pada orang lain dan mengatur dirinya sendiri. Pendidikan berarti pula sebagai daya upaya untuk memajukan pengembangan budi pekerti (kekuatan batin), pikiran ("intellect") dan jasmani. Maksudnya ialah supaya kita dapat memajukan kesempurnaan hidup, yakni kehidupan dan penghidupan peserta didik, selaras dengan alamnya dan masyarakatnya. Secara psikologis kedewasaan adalah di mana sudah ada ciri-ciri psikologis tertentu pada seseorang, diantaranya: Pertama, pemekaran diri sendiri yang ditandai dengan kemampuan seseorang untuk menganggap orang lain bagian dari dirinya sendiri. Perasaan egoisme berkurang dan muncul perasaan ikut memiliki. Kedua, kemampuan untuk melihat diri sendiri secara objektif dan mempunyai wawasan tentang diri sendiri. Ketiga, memiliki falsafah hidup tertentu ia paham kedudukannya dalam masyarakat dan tahu apa yang harus ia lakukan, Sarlito W Sarwono (2010).

Kebaikan dan kerusakan di dunia dan akhirat hanya dapat diketahui melalui syariat agama, orang tua mengenal anak sejak anak dilahirkan ke dunia, orang tua ialah orang yang paling mengetahui sifat dan karakter anak, setiap anak memiliki kekurangan dan kelebihan setiap anak adalah pribadi yang unik dan menarik dan orang tua selalu memantau perkembangan anaknya. Selain orang tua yang berperan terhadap anak ialah figur seorang guru, guru yang menyenangkan bagi anak didik, setiap kata yang di ucapkan guru pasti di dengar dan dipatuhi oleh seorang anak didik, keteladanan guru sangat berpengaruh pada sikap dan kepribadian anak didik.

Lingkungan sangat berpengaruh bagi anak, dan lingkungan ikut membentuk corak perilaku anak sebaiknya orang tua memilih lingkungan yang baik untuk anakanaknya.

\section{KESIMPULAN}

Pendidikan di masa usia dini merupakan fondasi awal pembentukan kepribadian seorang anak. Pendidikan merupakan suatu proses kehidupan manusia dengan tujuan mengimplementasikan nilai-nilai religius, nilai sosial 
Pendidikan Anak Perspektif Psikologi

kemasyarakatan dalam kehidupan seiring mengikuti perkembangan ilmu pengetahuan dan teknologi, upaya mengaktualisasikan potensi yang dimiliki untuk peningkatan ke tahap yang lebih baik.

Pendidikan anak perspektif psikologi perlu memahami dan mengimplementasikan hal berikut: Pertama, orang tua sebagai partner anak, disebabkan anak membutuhkan seseorang yang bisa menjadi tempat mencurahkan perasaan dalam menjalani petualangan. Orang tua sebagai orang yang dekat dengan anak selayaknya menjadi tempat bagi anak-anak untuk mencurahkan perasaannya. Melalui konsisten dalam mendidik anak, hadirnya keteladanan orang tua, pembinaan melalui penghayatan dan pengamalan agama. Kedua, guru yang kreatif, dengan menggairahkan anak didik, memberikan harapan realistis, seiring memberikan reward, dan mengarahkan perilaku anak didik. Ketiga, lingkungan yang baik. Lingkungan sangat berpengaruh bagi anak, dan lingkungan ikut membentuk corak perilaku anak sebaiknya orang tua memilih lingkungan yang baik untuk anak-anaknya.

\section{REFERENSI}

Akmal, H. (2014). Seluk Beluk Ilmu Jiwa Agama. Jakarta: Raja Grafindo Persada

Arvan, P. (2010). The 7 Laws of Happiness. Bandung: Kaifa

Bimo, W. (2010). Pengantar Psikologi Umum. Yogyakarta: ANDI

Chairinniza, G. (2007). Keberhasilan Anak Tergantung Orang Tua. Jakarta: Gramedia

Irfan, E. (2010). Keajaiban Berfikir Positif. Yogyakarta: Media Baca

Muhibin, S. (2015). Psikologi Belajar. Jakarta: Raja Grafindo Persada

Rohmalina, W. (2015). Psikologi Belajar. Jakarta: Raja Grafindo Persada

Rosleni, A. (2015). Psikologi Islam. Bandung: Pustaka Setia

Sarlito, W. S. (2010). Psikologi Remaja. Jakarta: Raja Grafindo Persada

Sri, R., \& Siti, S. (2004). Perkembngan Anak Dan Remaja. Jakarta: Rineka Cipta

Syamsu, Y. (2008). Psikologi Perkembangan Anak Dan Remaja. Bandung: Rosda Karya

Zakiah, D. (2010). Ilmu Jiwa Agama. Jakarta: Bulan Bintang 